\title{
A CASE STUDY OF LANGUAGE SHIFT IN PROGRESS IN PORT LIMON, COSTA RICA
}

\author{
Marva Spence Sharpe
}

\begin{abstract}
RESUMEN
Este trabajo presenta los resultados de la investigación llevada a cabo entre la población hablante de inglés criollo de Puerto Limón, Costa Rica. La comunidad criolla de Limón está en el proceso de cambiar su criollo de base inglesa por el español, lengua nacional y oficial.
\end{abstract}

\begin{abstract}
This paper presents the findings of research carried out among the creole-speaking population in Port Limon, Costa Rica. The Limon Creole community is in the process of shifting from speaking an English-based creole to speaking the national and official language, Spanish.
\end{abstract}

\section{Introduction}

Most people outside of Central America are unaware that English-based creole is spoken on the Atlantic or Caribbean Coast from Belize to Panama; Costa Rica is no exception. Limon Creole has been the native language of the black population in Port Limon, the population which this study treats. Port Limon is the largest urban center on the Atlantic Coast of Costa Rica. There are three main languages spoken in the province of Limon among the black population. Spanish, the official state language, Standard Limon English (SLE), used mainly for religious services and other institutionalized situations, and Limon Creole (a historical descendant of Jamaican Creole). Locally, Limon Creole is also referred to as Mek-ay-tel-yu, Patois, or English.

Since the 1950's the Limon Creole community has been experiencing social and economic pressures to become more fully incorporated into the larger community. Not surprisingly, these pressures have led to a greater willingness on the part of the black population to acquire the national language, Spanish. While the advantages of being bilingual are recognized in some quarters, mainly by the members of the upper stratum of the Limon Creole speech community, the great majority of blacks in Port Limon do not see any need to retain the ancestral language, Limon Creole. 
As a member of the Limon Creole speech community I am aware that a linguistic shift is taking place. I have seen the gradual changes through the different generations of my own family, from my grandparent who were Limon Creole monolinguals to my son and his generation who are Limon Creole semilinguals. Nevertheless, no linguistic study which shows the degree to which Limon Creole speakers have shifted to the use of the national language has been done. As a result, the present research aims at measuring the direction and magnitude of the sociolinguistic changes, with different interlocutor types, among Limon Creole speakers.

\subsection{History of the Atlantic Coast}

The forces that determine the flourishing or the decline of a language are rarely linguistic. They have to do with political, economic, social, educational, demographic, generally extralinguistic factors. Therefore, the linguistic changes of Costa Rican blacks today can be better understood within the context of the historic changes of Costa Rica as a whole.

Olien (1965) identifies three periods in the history of Costa Rica that have had repercussion on Costa Rican blacks: (1) the colonial period, (2) the construction of the railroad and the presence of the United Fruit Company in the lowlands (1871-1948), and (3) the period of social and legal reforms (1948-1953), marked by the revolution of 1948 and its aftermath which meant the first opportunity that the black population had to acquire political opportunities. He attaches three different types of blacks to these different socio-historical periods:

(1) the African Black,

(2) the West Indian Black, and

(3) the Costa Rican Black, the group with which this study deals.

\subsection{Period of Social and Legal Reforms and the Birth of the Costa Rican Blacks}

The period between 1942 and 1953 is considered crucial in the socio-economic transformation of the country. The third group of blacks, the blacks with Costa Rican citizenship, emerged during this period. In Port Limon, this period was marked by the departure of the United Fruit Company, which had heavy repercussions throughout the country but especially in Limon.

The departure of the United Fruit Company meant that the means of production fell into the hands of the state, and the Costa Rica government gained control of the province of Limon. The process was accompanied by significant demographic changes, with Hispanics starting to migrate more heavily to Limon, seeking land and economic opportunities, and in effect, Limon, a closed community under the plantation economy, became incorporated into the wider society. Thus the process of socio-political and linguistic integration began. The new Costa Ricans realized that their socio-economic survival depended in large measure on being accepted by the Costa Rican society and that the path to socio-economic mobility was through the national education system. Therefore, becoming Costa Rican citizens brought along with it cultural and linguistic changes. 


\title{
2. Code Choice and Acculturation
}

Standard Limon English, though previously the main symbol of prestige and opportunity, has lost ground to Spanish. This is understandable in the sense that the ability to function within the framework of Costa Rican society requires that the national language be spoken. The acculturation into the mainstream culture is accelerating. Mainly, younger generation blacks are swiftly moving into white collar jobs, a move which has further encouraged blacks to accept the cultural symbols and ideology of the dominant group. In addition, some blacks lured by the prospect of educational and economic betterment have shifted to speaking the national language and even deny any knowledge of Limon Creole.

The swift acculturation of the younger generations of Limon blacks is well described by Purcell (1982:355)

\begin{abstract}
(...) it is not unusual to encounter third-and fourth-generation migrants who do not speak English or creole, do not eat West Indian foods, and do not participate in their ancestral folk-life and even some who would rather not be associated with anything outwardly "Jamaican." (...) the pattern is for urban upwardly mobile Afro-Costa Ricans to assimilate at a higher rate. It is they who, depending on the path of mobility they have chosen, have had to demonstrate their ability to achieve the cultural and social standards of the dominant group.
\end{abstract}

\section{Literature on Language Shift}

Language death is a "metaphorical name" for linguistic extinction and has become widely used since the publication of Dorian's work of the same name. It occurs when a community shifts completely to the use of a new language so that the old language is no longer used. There are two definitions for language death or shift. The broad definition indicates the absolute extinction of a language, a state in which there is not one speaker of a certain language left in the world. The narrow definition refers to a complete shift to a new language in a given community.

In the study of language shift, one can either know what the trends or results are in isolated cases, or one can know how to find these out, but there is very little understanding of causal factors, according to Fasold (1984). Some of the commonly suggested factors in bringing about shift are: urbanization (Gal 1979, Timm 1980, Dorian 1981), school language and other government pressures (Dressler and Wodak-Leodolter 1977, Gal 1979, Kahane and Kahane 1979, Dorian 1981), industrialization (Dressler 1977, Gal 1979, Timm 1980, Dorian 1981) and migration (Dressler 1977, Gal 1979, Timm 1980, Dorian 1981). The main problem lies in being able to isolate independent variable(s) that can be generalized to other contexts.

The underlying social causes, present in other parts of the Western world, also surface in the case of Limon Creole:

a more permeable social stratification due to educational programs and other acculturative forms to foster social mobility;

(2) the influx of the majority population into Port Limon; 
(3) industrialization and commercialization;

(4) exogamy and;

(5) unfavorable attitudes toward Limon Creole.

\section{Methodology}

The population to be studied in this research is the black Limon Creole speakers in the city of Limon.

The respondents were selected mainly on the basis of their accessibility to the researcher and their willingness to participate. Extra care was taken to get informants from the different neighborhoods that make up the city. The ultimate criterion for choice of subjects was that the black Creole-speaking individual was born and raised in the province of Limon and was currently residing there.

A questionnaire consisting of 75 items was the basic research instrument. It was administered to 70 respondents in Spanish or in English, depending on the respondent's request.

In order to prevent obtaining a sample of only a very few households in each neighborhood, I avoided giving a questionnaire to more than one member of the same house. The questionnaire elicited information on the language use of the respondents with different interlocutors.

The interlocutor types are not exhaustive for the Limon Creole Speakers. The purpose of choosing most of the interlocutor types (eight) related to the family (grandparents, parents, aunts and uncles, spouse, children, grandchildren, siblings and nices and nephews) is to find out to what extent Spanish has permeated an aspect of the Limon Creole life that was once dominated by the ancestral language.

\section{1. $\quad$ Age Cohort}

A number of scholars including Fishman (1966), Gal (1979), Dorian (1981) and Fasold (1984) have found that generation difference is the most important variable in the prediction of ethnic mother-tongue displacement and that with each succeeding generation there is greater displacement of the ethnic mother-tongue.

Thus, it is plausible that among black Limonenses age will be a positive predictor of language shift. The respondents, in this study, range in age from 11 years to 102 years. Calculated from the raw data prior to categorization, the average age of the respondents is 30 years.

\subsection{Systematization of Data}

As a means of systematizing variation among Spanish, Limon Creole, and Spanish and Limon Creole, an implicational scale was developed. The scale depicts the speaker's choice depending on the role relationship of the interlocutor.

The use of Spanish, with an interlocutor, indicates that Spanish is used with all interlocutors to the right, and Limon Creole/Spanish (cs) or Limon Creole alone (c) is used with all in- 
terlocutors to the left of it. Use of both Spanish and Limon Creole is indicated by (cs). The instances in which the respondent reports using both codes does not mean that $\mathrm{s} / \mathrm{he}$ is engaged in code switching. It might be the case that sometimes, depending on, for example, the situational pressures, topic, location and number of interlocutors, the speaker might choose Limon Creole and, on other occasions, s/he might choose Spanish, with the same interlocutor.

The sequence of focus of the scale is a continuum from strong Limon Creole dominance to strong Spanish dominance. For this study, speakers are ordered by rows, with most of the younger speakers appearing at the top and the older ones at the bottom. The interlocutor types are numbered 1 through 12. Individual speakers are ranked on the vertical axis. Each row of letters represents the language choice of one respondent and each letter the language chosen. Each language was given a value: Limon Creole (1), Spanish/Limon Creole (2) and Spanish (3). The values were used to test the scalability of the table.

The index of language use for a respondent was computed by adding the values along the horizontal axis and dividing them by the number of applicable cells for that respondent. Therefore, if a respondent uses Spanish exclusively his/her index score is (3.00).

\section{Table 1}

\section{Impicational scale for language choice}

Interlocutors

INDEX OF

Lg. USE

$\begin{array}{lllllllllllllll}\text { Res } & \text { AGE } & 1 & 2 & 3 & 4 & 5 & 6 & 7 & 8 & 9 & 10 & 11 & 12 \\ 1 & 11 & \text { s } & \text { s } & \text { s } & - & - & - & \text { s } & \text { s } & - & \text { s } & \text { s } & - & 3.00 \\ 2 & 14 & \text { s } & \text { s } & \text { s } & - & - & - & \mathrm{s} & \mathrm{s} & - & \mathrm{s} & \mathrm{s} & - & 3.00 \\ 3 & 12 & \mathrm{~s} & \mathrm{~s} & \mathrm{~s} & - & - & - & - & \mathrm{s} & - & \mathrm{s} & \mathrm{s} & - & 3.00 \\ 4 & 15 & \mathrm{~s} & \mathrm{~s} & \mathrm{~s} & - & - & - & \mathrm{s} & \mathrm{s} & - & \mathrm{s} & \mathrm{s} & - & 3.00 \\ 5 & 16 & \mathrm{~s} & \mathrm{~s} & \mathrm{~s} & \mathrm{~s} & \mathrm{~s} & - & \mathrm{s} & \mathrm{s} & - & \mathrm{s} & \mathrm{s} & - & 3.00 \\ 6 & 34 & \mathrm{cs} & \mathrm{s} & - & \mathrm{s} & - & - & \mathrm{s} & \mathrm{s} & \mathrm{s} & \mathrm{s} & \mathrm{s} & \mathrm{s} & 2.88 \\ 7 & 33 & \mathrm{cs} & \mathrm{s} * & \mathrm{cs} & \mathrm{cs} & \mathrm{s} & - & \mathrm{s} & \mathrm{s} & \mathrm{s} & \mathrm{s} & \mathrm{s} & \mathrm{s} & 2.73 \\ 8 & 46 & - & \mathrm{c} & \mathrm{s} & \mathrm{s} & \mathrm{s} & \mathrm{s} & \mathrm{s} & \mathrm{s} & \mathrm{cs} * & \mathrm{~s} & \mathrm{~s} & \mathrm{~s} & 2.73 \\ 9 & 12 & \mathrm{cs} & \mathrm{s} & \mathrm{cs} * & - & - & - & \mathrm{s} & \mathrm{s} & - & \mathrm{s} & \mathrm{s} & - & 2.71 \\ 10 & 29 & \mathrm{cs} & \mathrm{cs} & \mathrm{cs} & \mathrm{s} & \mathrm{s} & - & \mathrm{s} & \mathrm{s} & \mathrm{s} & \mathrm{s} & \mathrm{s} & - & 2.70 \\ 11 & 30 & \mathrm{c} & \mathrm{cs} & \mathrm{s} & - & \mathrm{s} & - & \mathrm{s} & \mathrm{s} & - & \mathrm{s} & \mathrm{s} & \mathrm{s} & 2.67 \\ 12 & 17 & \mathrm{cs} & \mathrm{s} & \mathrm{cs} * & - & - & - & - & - & - & - & \mathrm{s} & - & 2.50 \\ 13 & 37 & \mathrm{c} & \mathrm{c} & \mathrm{cs} & \mathrm{s} & \mathrm{s} & - & \mathrm{s} & \mathrm{s} & \mathrm{cs} * & \mathrm{~s} & \mathrm{~s} & \mathrm{~s} & 2.45 \\ 14 & 39 & \mathrm{c} & \mathrm{c} & \mathrm{c} & \mathrm{s} & \mathrm{s} & - & \mathrm{s} & \mathrm{s} & \mathrm{s} & \mathrm{s} & \mathrm{s} & \mathrm{s} & 2.45 \\ 15 & 44 & \mathrm{c} & \mathrm{cs} & - & \mathrm{s} & \mathrm{s} & - & \mathrm{cs} * & \mathrm{cs} & \mathrm{cs} & \mathrm{s} & \mathrm{s} & \mathrm{s} & 2.40 \\ 16 & 44 & - & - & \mathrm{c} & - & \mathrm{s} & \mathrm{s} & \mathrm{s} & \mathrm{cs} * & \mathrm{cs} & \mathrm{s} & \mathrm{cs} * & - & 2.37 \\ 17 & 14 & \mathrm{cs} & \mathrm{cs} & \mathrm{cs} & - & - & - & - & \mathrm{cs} & - & \mathrm{s} & \mathrm{s} & - & 2.33 \\ 18 & 35 & \mathrm{c} & \mathrm{cs} & - & \mathrm{s} & \mathrm{s} & - & \mathrm{cs} * & \mathrm{cs} & - & \mathrm{s} & \mathrm{cs} * & \mathrm{~s} & 2.33 \\ 19 & 18 & \mathrm{cs} & \mathrm{cs} & \mathrm{cs} & - & - & - & \mathrm{cs} & \mathrm{cs} & \mathrm{cs} & \mathrm{cs} & \mathrm{s} & \mathrm{s} & 2.22 \\ 20 & 27 & \mathrm{cs} & \mathrm{cs} & \mathrm{s} * & - & \mathrm{cs} & - & \mathrm{cs} & \mathrm{cs} & \mathrm{cs} & \mathrm{cs} & \mathrm{cs} & \mathrm{s} & 2.20 \\ 21 & 17 & \mathrm{cs} & \mathrm{cs} & \mathrm{cs} & - & - & - & \mathrm{cs} & \mathrm{s} & - & \mathrm{cs} * & \mathrm{cs} & - & 2.14 \\ 22 & 26 & \mathrm{c} & \mathrm{cs} & \mathrm{s} * & \mathrm{cs} & - & - & \mathrm{cs} & \mathrm{cs} & \mathrm{cs} & \mathrm{cs} & \mathrm{cs} & \mathrm{s} & 2.10\end{array}$


Continuación...

\section{Interlocutors}

INDEX OF

Lg. USE

$\begin{array}{lllllllll}23 & 50 & \mathrm{c} & \mathrm{c} & \mathrm{c} & - & \mathrm{cs} & - & - \\ 24 & 49 & \mathrm{c} & \mathrm{c} & \mathrm{c} & \mathrm{c} & \mathrm{c} & \mathrm{cs} * & \mathrm{c} \\ 25 & 68 & - & - & \mathrm{c} & \mathrm{c} & - & \mathrm{c} & \mathrm{cs} * \\ 26 & 70 & - & - & \mathrm{c} & \mathrm{cs} * & \mathrm{c} & \mathrm{c} & \mathrm{c} \\ 27 & 70 & - & - & \mathrm{c} & \mathrm{c} & \mathrm{c} & \mathrm{c} & \mathrm{c} \\ 28 & 102 & - & - & - & \mathrm{c} & \mathrm{c} & \mathrm{c} & -\end{array}$

$\begin{array}{lllll}\mathrm{c}^{*} & \mathrm{~s} & - & \mathrm{s} & 1.86 \\ \mathrm{c} & \mathrm{c} & \mathrm{s} & - & 1.27 \\ - & - & - & - & 1.20 \\ \mathrm{c} & \mathrm{c} & - & - & 1.12 \\ \mathrm{c} & \mathrm{c} & - & - & 1.00 \\ \mathrm{c} & \mathrm{c} & - & - & 1.00\end{array}$

c $=$ Limon Creole, $c s=$ Limon Creole and Spanish, $\mathrm{s}=$ Spanish

Total number of cells $=233$

Inapplicable cells $=103(31 \%)$

*These cells fail to conform to perfect implicational scaling

Scalability $=92.7 \%$

Spearman's Rho--.68

\section{INTERLOCUTORS}

1. grandparents

2. parents

3. aunts and uncles

4. spouse

5. children, offspring

6. grandchildren

7. siblings

8. children of neighbors

9. nieces and nephews

10. friends

11. classmates

12. co-workers

\section{Language Choice Depending on the Interlocutor}

In the Limon Creole speech community language choice is affected by the identity of the interlocutor which tells us that it is imposible to isolate any single factor for language choice. Weinreich (1966) comments that when speaking to a monolingual, the bilingual often tends to limit interference. But when the interlocutor is also bilingual, interference is hardly limited which might be the reason why the respondents ranked in the middle of the implicational array (respondents fifteen through twenty-two) claim to use both Limon Creole and Spanish with the different interlocutors.

\subsection{Language Use Patterns}

Limon Creole is still spoken in families having grandparents. Nevertheless, respondents aged 11-35 usually speak to their grandparents in both Limon Creole and 
Spanish. In general more of the younger grandchildren aged 11-17 choose to speak Spanish to grandparents.

Parents also are spoken to in both languages. Older parents are spoken to mainly in Creole. Respondents over age thirty-seven tend to speak to their parents mainly in Limon Creole.

The younger respondents claim to use more Spanish with parents. I visited nine households with teenagers and Spanish dominated in these households, which agrees with their responses.

When asked what language they speak with their spouses, twenty-six of thirty-five respondents indicated that they use Spanish or Spanish/Limon Creole, and nine indicated Limon Creole.

An indication of the dominance of Spanish in the home is seen in the language parent respondents use with their children. It is interesting that a seventy-year-old female respondent speaks both Limon Creole and Spanish with her spouse. Thirty-one of thirty-five reported conversing with their children in Spanish or Limon Creole/Spanish and only four in Limon Creole exclusively. My observation revealed that even though spouses might choose to speak Limon Creole among themselves, they would switch to Spanish when speaking to their children.

Younger grandparents use both languages or Spanish alone with their grandchildren. And, as is expected, the older grandparents speak to their grandchildren in Limon Creole. Even though grandparents are underrepresented (seven total), it is important to notice that grandchildren seem to be speaking more Spanish or Limon Creole/Spanish to their grandparents (column 1). This pattern is congruent with what I observed in households of three generations living together.

In the table above, the majority of the interlocutor types could be categorized as belonging to the intimate aspect of the repondent's lives. Nevertheless, it appears that the Limon Creole speaker (especially the younger speaker) is unable to exclusively use Limon Creole with those interlocutors considered more intimate, such as grandparents, parents, spouse, children, grandchildren and siblings.

The Limon Creole language interaction between parent and child or grandmother and grandchild is not taking place today as it once did. In the past, the native LC speaker learned the mother tongue from parents and grandparents. Today, many parents choose Spanish as the language of interaction with their children.

This table also shows that when the respondent's addressee is a friend, co-worker, classmate or neighbor there is an inclination to use the dominant language. The choice of Spanish with friends, co-workers and classmates may evidence assimilation or attempt at assimilation by a Limon Creole speaker into the dominant culture.

However, this does not mean that, on the other hand, Limon Creole is the sole language to be used in family situations. If we look at the pattern of language choice with family members (columns 1 through 7 and column 9), it is apparent that Spanish leads the way. It is used in $43 \%$ of the cases, followed by Limon Creole/Spanish $31 \%$ and Limon Creole lagging behind $26 \%$, as seen in Table 2. 
Table 2

\title{
Language Use Patterns With Family Members
}

$\begin{array}{lll} & \mathbf{N} & \text { \% } \\ \text { S } & 60 & 43 \\ \text { CS } & 43 & 31 \\ \mathbf{C} & 37 & 26\end{array}$

Total cells 140

\section{Implications for Language Shift}

Terry Wolfe (1981: 231) made the following observation about the linguistic situation in Limon:

\begin{abstract}
In 1970 the Black Limonense was not totally accepted into the mainstream of the traditional Costa Rican culture. Many of those blacks born before 1940 don't refer to themselves as Costa Ricans although they accept the fact that they are Costa Rican citizens. Those blacks born afterthe 1940s strongly identify themselves with Costa Rica and the traditions of the country. In predicting the future of the English language, one must confirm that it is this generation which will be the deciding factor; it will be necessary to look at this problem more closely.

The future of the English language in Limon depends on the resistance or lack of resistance of this generation to assimilate into the mainstream culture.
\end{abstract}

Table 1 reveals that the amount of Spanish used by younger people increases substantially. For Limon Creole to be maintained the younger people must put out some effort and continue to use it. That is not taking place. The younger generations, in this study, are not ensuring that the language is passed on to their children (see Table 1, column 5) in spite of the fact that it is rare to hear anyone express an aversion to Limon Creole.

A correlation was done to measure the relationship between identity of interlocutor and the ranked age of respondents. The result shows that there is a relationship $(\mathrm{r}-.68)$, which suggests that, in this case, age is one of the determinants for language shift.

It is my hope that the patterns of language use that emerge from this study have shed some light on the current linguistic situation of the black population in Port Limon.

At this point it is important to consider the possibilities that await Limon Creole. First, Limon Creole may be totally replaced by Spanish and not spoken any more by members of the community. A second possibility however, is that Limon Creole may not be completely abandoned and instead it will be maintained as a second language, resulting in reverse bilingualism. Thus, two types of language shift can occur: language shift with Limon Creole loss and language shift with Limon Creole maintenance. Another possible outcome is that the offsprings of the most affluent classes may increasingly acquire English as a second language ${ }^{1}$. Nevertheless, this scenario would not contribute to the retention of Limon Creole. 


\section{Notes}

1. Today, many families that can afford it are sending their children to private schools to learn English

\section{References}

Bradley, David. 1989. "The Disappearance of the Ugong in Thailand." Investigating Obsolescence: Studies in Language Contraction and Death. Nancy Dorian (ed.). Cambridge: Cambridge University Press.

Bryce Laporte, Roy S. 1962. "Social Relations and Cultural Persistence Among Jamaicans in a Rural Area of Costa Rica." Diss. Institute of Caribbean Studies, University of Puerto Rico.

Cooper, Robert. 1982. Language Spread: Studies in Diffusion and Social Change. Bloomington, Indiana: Indiana University Press.

Cooper, Robert and Joshua Fishman. 1974. "The Study of Language Attitudes" International Journal of the Sociology of Language. 3: 5-19.

De Camp, David. 1971. "Toward a Generative Analysis of a Post-Creole Speech Community." Pidginization and Creolization of Languages. Hymes, Dell (ed.). Cambridge: Cambridge University Press.

Denison, Norman. 1977. "Language Death or Language Suicide?" International Journal of the Sociology of Language. 12: 13-22.

Dimmendal, Gerrit J. 1989. "On Language Death in Eastern Europe.” Investigating Obsolescence: Studies in Language Contraction and Death. Nancy Dorian (ed.). Cambridge: Cambridge University Press.

Dorian, Nancy. 1981. Language Death: The Life Cycle of a Scottish Gaelic Dialect. Philadelphia, Pennsylvania: University of Pennsylvania Press.

1980. "Language Shift in Community and Individual: The Phenomenon of the Laggard Semi-speaker." International Journal of the Sociology of Language. 25: 85-94.

Fasold, Ralph. 1984. The Sociolinguistics of Society. Oxford: Basil Blackwell Publisher.

Fishman, Joshua. 1964. "Language Maintenance and Shift as Fields of Inquiry." Linguistics 9: 32-70.

Gal, Susan. 1979. Language Shift Social Determinants in Bilingual Austria. New York: Academic Press. 
Jones-Jackson, Patricia. 1987. When Roots Die: Endangered Traditions on the Sea Islands. Athens Georgia: University of Georgia Press.

Purcell, Trevor W. Banana Fallout: Class, Color and Culture among West Indians in Costa Rica. Los Angeles: Center for Afro-American Studies Publications, University of California.

Timm, Lenora. 1980. "Bilingualism, Diglossia and Language Shift in Brittany." International Journal of the Sociology of Language. 25: 29-42.

Weinreich, Uriel. 1968. Languages in Contact: Findings and Problems. The Hague: Mouton. 